FACTA UNIVERSITATIS

Series: Physical Education and Sport, Vol. 17, No 2, 2019, pp. 195 - 203

https://doi.org/10.22190/FUPES190904020J

Research article

\title{
INFLUENCE OF CERTAIN MOTOR ABILITIES ON BALL THROWING VELOCITY IN GOALBALL: A PILOT STUDY
}

\author{
UDC 796.015.527.328 \\ 796.015 .53 .328
}

\author{
Bojan Jorgić ${ }^{1}$, Aleksandra Grbović ${ }^{2}$, Stefan Đorđević ${ }^{1}$, \\ Veroljub Stanković ${ }^{3}$, Ratko Stanković ${ }^{1}$ \\ ${ }^{1}$ Faculty of Sport and Physical Education, University of Niš, Niš, Serbia \\ ${ }^{2}$ Faculty for Special Education and Rehabilitation, \\ University of Belgrade, Belgrade, Serbia \\ ${ }^{3}$ Faculty for Sport and Physical Education, Leposavić, \\ University of Priština, Leposavić, Serbia
}

\begin{abstract}
The aim of the research was to determine the influence of sprint performance and explosive strength on ball throwing velocity in Goalball. The sample of participants consisted of 12 nationally and internationally ranked Goalball players,

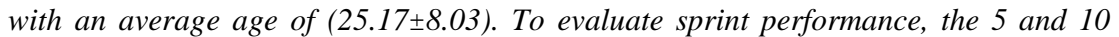
meter sprint tests were used. To evaluate explosive strength, the standing long jump and seated medicine ball throw were used. The results of the regression analysis have indicated that the entire system of applied variables is statistically significantly connected and influences ball throwing velocity. At the same time, we evaluated the statistically significant influence of the seated medicine ball throw variable. We can conclude that as part of the fitness training of Goalball players, it is necessary to work on improving sprint performance and explosive strength due to the ability of rapid transition of the players from the defensive phase to the attack phase. It is especially important to develop upper-body explosive strength in order to increase ball throwing velocity and create the possibility for greater effectiveness of Goalball players.
\end{abstract}

Key words: Explosive Strength, Sprint Performance, Training, Effectiveness

Received September 04, 2019/ Accepted September 14, 2019

Corresponding author: Bojan Jorgić

Faculty of Sport and Physical Education, University Niš, St. Čarnojevića 10a, 18000 Niš, Serbia

Phone: +381 18510900 •E-mail: bojan.jorgic@fsfv.ni.ac.rs 


\section{INTRODUCTION}

Goalball is a team sport for individuals with visual impairment which originated in 1946 and was designed by Hanz Lorenzen and Sepp Reindletog. It is played by three players each on opposing teams with a ball with bells inside, on a court $18 \times 9$ meters in size, with a goal that is $9 \mathrm{~m}$ wide and $1.30 \mathrm{~m}$ tall. The goal of the game is for a team, following the successful defense of its goal, to throw the ball towards the opponent's goal and score a goal (Davis, 2011). Goalball appeared for the first time at the Paralympic games in Toronto, Canada, in 1976, and the first Goalball World Championship was held in Vocklamarkt, Austria in 1978 (Van Rheenen, 2016). Goalball is an authentic Paralympic sport considering that it does not have a counterpart in the Olympic program, such as seated volleyball, wheelchair basketball, etc. Considering that, in terms of technical, tactical and fitness preparation, the information from the existing Olympic sports could not be used, new knowledge and elements of the training process in Goalball had to be developed.

In terms of fitness preparation Atan \& Ayca (2015) determined that Goalball training can be used to develop strength, speed, flexibility, explosive strength, speed of motor reactions, etc. among visually impaired individuals. Karakaya, Aki, \& Ergun (2009) determined greater values of motor skills among Goalball players compared to less active age-matched adolescents without visual impairment. In addition, higher values of motor skills were determined in comparison to blind individuals involved in Goalball (Çolak, Bamaç, Aydin, Meriç, \& Özbek, 2004). Research was carried out in which the morphological and nutritional status of Goalball players were evaluated (Calıskan et al., 2011; Scherer, Karasiak, da Silva, \& Petroski, 2012), as well as their postural status (Đorđević, Mitrović, Zrnzević, Kudlaček, \& Jorgić, 2018). In the studies of (Link \& Weber, 2018; Monezi et al., 2019) the difference in the effectiveness and time-motion variables of various ball techniques throwing and player positions were analyzed. Reserach has also been carried out which studied game performance in Goalball (Molik et al., 2015; Jorgić, Aleksandrović, Živković, Utvić, \& Popović, 2018). A smaller number of studies were carried out with the aim of determining the motor abilities (Paravlić et al., 2015) and their influence on ball throwing velocity in Goalball (Utvić, Arsenijević, \& Lilić, 2018). According to (Morato, Menezes, Fonseca, \& Furtado, 2018), the greatest influence on scoring goals was determined to originate from ball throwing velocity.

As a result, it is necessary to determine which motor abilities should be developed during the training process in order to increase throwing velocity and thus effectiveness. Some of the motor abilities which are developed during Goalball training, such as explosive strength, are considered to have an influence on the increase of throwing velocity, considering the way the game is played, the elements of technique, and the rules. Based on the aforementioned, the aim of this research was to determine the influence of sprint performance and explosive strength on ball throwing velocity in Goalball.

\section{METHODS}

\section{The sample of participants}

The research was carried out on a sample of 12 Goalball players of an average age of $25.17 \pm 8.03$ years $($ Mean \pm SD). The Goalball players were nationally and internationally ranked. International ranking requires that players participate in international games 
organized as a part of Goalball tournaments, and national ranking requires them to participate in national championships. In relation to the level of visual impairment, according to Goalball classification, the structure of the participants consists of two B1 category players, eight B2 category players, and two B3 category players. All of the players wore blindfolds during the testing.

\section{The sample of variables}

Testing was carried out during Goalball camp. To evaluate explosive strength, the Standing long jump and Seated medicine ball throw tests were used. To evaluate sprint performance, the $5 \mathrm{~m}$ and $10 \mathrm{~m}$ sprint tests were used. To evaluate explosive strength of the arms ball throwing velocity test was performed. All of the testing was carried out under the same environmental conditions (temperature: $28.0 \pm 0.7^{\circ} \mathrm{C}$; humidity: $41.2 \pm 4.0 \%$ ). No trial attempts were made prior to the testing to avoid any motor learning effect.

\section{The Standing long jump - SLJ}

This test is used to evaluate the explosive strength of the legs. It was carried out following a standardized procedure (Castro-Piñero et al., 2009). The participant stands behind the starting line, feet parallel. The task is to jump forward using the explosive strength of the leg muscle. The distance is measured from the starting line to the heel print nearest to the starting line. The distance is measured in $\mathrm{cm}$. The test was performed three times, and the best attempt was used as the overall score. This test has been used among athletes with visual impairment (Karakoc, 2016).

\section{The Seated medicine ball throw - SMBT}

The test is used to evaluate upper-body explosive strength. The participant sits on the floor, back against a wall, legs fully extended, splay-footed. The participant holds a medicine ball, which weighs $2 \mathrm{~kg}$, using both hands, close to the chest, similar to a pass position in basketball. The task is to throw the ball in a straight line as far as possible, without the back breaking contact with the wall. The distance is measured in $\mathrm{cm}$. The test was performed three times, and the best result was recorded as the final score. The test reliability was confirmed in the research of (Van den Tillaar \& Marques, 2013).

\section{The 5 meter sprint test - $5 \mathrm{mST}$ and 10 meter sprint test - $10 \mathrm{mST}$}

These tests are used to evaluate sprint performance at distances of 5 and 10 meters (Ellis et al., 2000). Electronic timing gates (Witty system, Microgate, Bolzano, Italy) were set on the starting line, and at distances of 5 and 10 meters from the line, and were used to measure the sprint time in seconds. Photocells were set at hip height to ensure that only one part of the body would activate them the moment when the participant passes through the timing gate (Yeadon, Kato, \& Kerwin, 1999). The participants assumed the position of the high start, $50 \mathrm{~cm}$ behind the starting line, and were instructed to run as fast as possible covering a distance of 5 and 10 meters. At a distance of 20 meters from the starting line there was instructor who provided auditory guidance regarding the direction of the sprint, considering that the participants were visually impaired. Each participant performed three attempts with a 60s break in between. The best result was included in the final analysis. Duthie, Pyne, Ross, Livingstone, \& Hooper (2006) confirmed the reliability of the 10mST. 


\section{Ball throwing velocity - BTV}

This test was used to evaluate ball throwing velocity in Goalball. Ball velocity was measured using electronic timing gates (Witty system, Microgate, Bolzano, Italy) which were synchronized with customized software and expressed in $\mathrm{m} / \mathrm{s}$. One gate was positioned at the $6 \mathrm{~m}$ line which represents the high ball line before which the thrown ball must first touch the surface before it can be thrown at the opponent's goal. The second gate was positioned at the line of the opponent's goal. Ball throwing velocity was measured at a distance of 12 meters. The participant, in accordance with the rules of Goalball, is tasked with throwing the ball into the opponents' goal, so that it first makes contact with the surface before the high ball line where, as previously mentioned, the first gate is located. The players threw the ball using the technique which most suited them. The throw was performed three times, and the best score included in further analysis.

\section{Statistical analysis}

All of the obtained data are represented by descriptive parameters: means, standard deviation - SD, minimal - Min and maximal - Max results. To determine whether the distribution of the results is normal, the Kolmogorov-Smirnov test was used. To determine the influence of the entire predictor system of variables on the criterion variables, a regression analysis was used, which determined the following statistical parameters: the multiple correlation coefficient $(\mathrm{R})$, coefficient of determination $\left(\mathrm{R}^{2}\right)$, the F-test $(\mathrm{F})$, and the level of statistical significance $(\mathrm{p})$. To determine the influence of each individual variable in the regression analysis, the following was calculated: the partial correlation coefficient (part-r), the correlation coefficient (r), standardized coefficient of the partial regression (Beta), the t-test (t), and the level of statistical significance (p). The level of statistical significance was set at $0.05(\mathrm{p}$ $\leq 0.05$ ). The data was processed using the statistical package Stat soft-Statistica 8.0.

\section{RESULTS}

The results of the Kolmogorov-Smirnov test are shown in Table 1 and indicate that the distribution of the obtained results does not deviate statistically significantly from the normal distribution of all the variables, since the value of $\mathrm{p}$ exceeds 0.05 .

Table 1 The descriptive statistics of the applied variables

\begin{tabular}{lcccrc}
\hline Variables & Mean & Min & Max & \multicolumn{1}{c}{ SD } & K-S $(\mathrm{p})$ \\
\hline SLJ $(\mathrm{cm})$ & 197 & 165 & 245 & 21.64 & 0.997 \\
SMBT $(\mathrm{cm})$ & 456 & 230 & 790 & 140.46 & 0.738 \\
5mST $(\mathrm{s})$ & 1.32 & 1.14 & 1.57 & 0.13 & 0.592 \\
10mST $(\mathrm{s})$ & 2.18 & 1.93 & 2.41 & 0.16 & 0.969 \\
BTV $(\mathrm{m} / \mathrm{s})$ & 1.59 & 0.92 & 3.13 & 0.58 & 0.549 \\
\hline
\end{tabular}

Legend: SLJ - standing long jump, SMBT - seated medicine ball throw, $5 \mathrm{mST}$ - 5m sprint test, $10 \mathrm{mST}$ - 10m sprint test, BTV - ball throwing velocity, K-S (p) - the statistical significance of the Kolmogorov-Smirnov test 
Table 2 shows the results of the regression analysis of the influence of the applied tests for the evaluation of sprint performance and explosive strength on ball throwing velocity. The obtained results indicate that there was a statistically significant correlation within the entire system of predictor variables, which influenced ball throwing velocity $(p<0.038)$. The value of the multiple correlation coefficient $(R)$ was 0.85 . The coefficient of determination $\left(\mathrm{R}^{2}\right)$ has a value of 0.71 , which means that the shared variability is explained with $71 \%$.

Table 2 The influence of the applied tests for the evaluation of sprint performance and explosive strength on ball throwing velocity

\begin{tabular}{lrcrrc}
\hline Variables & Beta & Part-r & $\mathrm{r}$ & $\mathrm{t}(7)$ & $\mathrm{p}$-level \\
\hline SLJ & 0.58 & 0.49 & -0.42 & 1.52 & 0.172 \\
SMBT & -0.89 & -0.68 & -0.75 & -2.43 & $\mathbf{0 . 0 4 5}$ \\
5mST & 0.04 & 0.033 & 0.68 & 0.09 & 0.932 \\
10mST & 0.41 & 0.29 & 0.67 & 0.82 & 0.439 \\
\hline \multicolumn{5}{c}{$\mathrm{R}=0.85, \mathrm{R}^{2}=0.71, \mathrm{~F}(4,7)=4.62, \mathrm{p}=<\mathbf{0 . 0 3 8}$}
\end{tabular}

Legend: $\mathrm{R}$ - the multiple correlation coefficient, $\mathrm{R}^{2}$ - the coefficient of determination, $\mathrm{F}$ - the F-test, part- $r$ - the partial correlation coefficient, $r$ - the correlation coefficient, Beta - standardized coefficients of the partial regression, $\mathrm{t}$ - the t-test results, and $\mathrm{p}$ - the level of statistical significance.

Viewed individually, a statistically significant influence on ball throwing velocity was determined for the seated medicine ball throw at the $(p=0.045)$ level. The numeric negative value or negative sign $(B e t a=-0.89)$ actually represents a desired positive connection. This indicates that Goalball players who throw the medicine ball further score better results on ball throwing velocity in Goalball.

\section{DISCUSSION}

A sample of 12 nationally and internationally ranked Goalball players were included in this study with the aim of determining the influence of sprint performance and explosive strength on ball throwing velocity in Goalball. For that purpose a regression analysis was used. The results of the analysis have indicated that the entire system of variables for the evaluation of the explosive strength of the legs (the standing long jump), upper-body explosive strength (the seated medicine ball throw) and sprint performance (the sprint test on 5 and $10 \mathrm{~m}$ ) are connected in a statistically significant manner, and influence ball throwing velocity in Goalball. These results indicate that during the training process in Goalball, it is important to develop the explosive power of the legs and upper-body and sprint performance in order to increase ball throwing velocity. Explosive strength and velocity are important because of the ability to quickly transfer from the defensive phase to the attack phase. Following a successful defense, if the player has the ability to direct the caught ball towards the opponents' goal, while the players on the other team have not yet assumed their defensive positions, the chances of scoring a goal are higher. This is especially prominent in the later phases of the game, where better physical fitness of the players can bring an advantage to the game. 
Furthermore, explosive strength and sprint performance are also important for the 10 second rule. According to this rule the player, once he deflects the opponent's throw has 10 seconds to throw the ball towards the opponents' goal. If the attempt is unsuccessful, the referee signals a penalty for the opposing team (International Blind Sports Federation, 2019). As a result, it is important for the players to be able to react quickly and explosively. This reaction includes that players, after assuming a position on their side on the floor, which is the usual defensive position, quickly catch the ball, move to a standing position and after several run-up steps throw the ball towards the opponents' goal. This transition from the defensive phase to the attack phase takes place during the anaerobic work regime (dos Santos Alves et al., 2018) where explosive strength and ability to accelerate are manifested.

Viewed through the transition phases for an attack, the explosive strength of the legs is important because of the rapid transition from a defensive position (usually a lying position on one's side) to a standing position from which the attack phase continues. The test which is used to evaluate explosive strength (the standing long jump) is important in the selection of Goalball players (Abdullah, Hassan, Pilus \& Fauzee, 2018). In addition, (GoulartSiqueira et al., 2019) using the counter movement jump test (another test used to evaluate explosive strength), determined that the ball throw has a high correlation $(r=0.754 ; \mathrm{p}<$ 0.05 ) with the explosive strength of the legs.

The ability to develop velocity during the first 5 meters is important for the way in which most players perform a throw at the goal in Goalball. The distance from the goal line to the high ball line is 6 meters. This is the space into which the player, in accordance with the rules, must throw the ball toward the opponents' goal so that a personal penalty shot would not be called, also known as a high ball. The player moves from their goal and in only a few run-up steps moves towards the high ball line and then throws the ball, which according to (Morato, Gomes, \& Almeida, 2012) takes place during two phases: the preparation phase and the throwing phase. Considering the fact that movement with a ball and throwing a ball both take place in a space that does not exceed 6 meters, it is important to realize the greatest velocity and speed possible during those first few steps. Thus, the results of the 5 meter sprint are important indicators of the speed abilities of Goalball players. The 10 meter sprint results are important in Goalball as a standard test for the evaluation of the sprint performance of athletes.

In addition to the influence of the entire system of predictor variables, the Seated medicine ball throw used as a test to evaluate upper-body explosive strength, emerged as statistically significant predictor which influences ball throwing velocity in Goalball. The connection between motor skills and ball throwing velocity was studied by (Utvić et al., 2018). These authors determined that the medicine ball throw test had a medium high correlation ( $\mathrm{r}=0.64)$ with ball throwing velocity in Goalball. According to the research of (Morato et al., 2018) of the three studied parameters (ball trajectories, ball types, and ball time), the greatest influence on scoring goals was achieved by ball throwing velocity. This could indirectly have an influence on game efficiency, which is according to (Jorgić et al., 2018) one of the most important game parameters which determine the winner in Goalball. This indicates that during the training process, special attention should be dedicated to the development of upper-body explosive strength since ball throwing velocity significantly depends on it, and since is already being used in training sessions in other sports (Hermassi, Van den Tillaar, Khlifa, Chelly, \& Chamari, 2015). In addition, the results of the SMBT test can be used in the selection process of Goalball players. 
Considering that this is a pilot study, in order for the results to be applied in practice with any certainty, it is necessary to once again repeat the study on a larger sample of participants of various levels of competition of the $\mathrm{A}, \mathrm{B}$ and $\mathrm{C}$ division. Considering that there are various types of throws in Goalball (Link \& Weber, 2018), the influence of motor skills on every type of throw should be determined. This would enable us to see which of the players' motor skills should be developed in particular, depending on the type of throw they prefer. In addition, future research should include a group of predictor variables of tests which include the remaining motor skills which could also influence ball throw velocity (Bowerman \& Davis, 2012), and which were have so far been included in research involving Goalball players: agility, coordination, flexibility, etc.

\section{CONCLUSION}

The obtained results and their analysis indicate that the system of applied predictor variables used to evaluate explosive strength and sprint performance have a statistically significant influence on ball throwing velocity in Goalball. Viewed individually, a statistically significant influence was determined for the variable of the seated medicine ball throw. Based on the aforementioned it can be concluded that within the fitness training of Goalball players, more work should be done on the development of explosive strength and sprint performance. Work should be done on the development of upper-body explosive strength, so as to increase ball throwing velocity and create the possibility for the greater effectiveness of Goalball players.

Acknowledgement: This study is a part of the project "The biomechanical efficiency of top Serbian athletes", № OI 179019 funded by the Ministry of Education, Science and Technological Development of the Republic of Serbia.

\section{REFERENCES}

Abdullah, N., Hassan, N.A., Pilus, A.M., \& Fauzee, M.S.O. (2018). Comparison of sports-specific test protocol and procedures to identify talent in goalball between students with blind and visual impairment: A preliminary study. In N. Yacob, N. Noor, N. Yunus, R. Yussof \& S. Zakaria (Eds). Regional Conference on Science, Technology and Social Sciences (RCSTSS 2016), (pp. 1017-1026). Springer: Singapore.

Atan, T., \& Ayca, M. (2015). Effect of goalball sport on physical performance of visually impaired students. Journal of Social Science Research, 7(1), 1206-1212.

Bowerman, S.J., \& Davis, R. (2012). Research application. Phases of movement and ball velocity of the goalball throw: A pilot study. Palaestra, 26 (2), 5-7.

Calıskan, E., Pehlivan, A., Erzeybek, M.S., Kayapınar, F.C., Agopyan, A., Yuksel, S., \& Dane, S. (2011). Body mass index and percent body fat in goalball and movement education in male and female children with severe visual impairment. Neurology, Psychiatry and Brain Research, 17(2), 39-41.

Castro-Piñero, J., González-Montesinos, J.L., Mora, J., Keating, X.D., Girela-Rejón, M.J., Sjöström, M., et al. (2009). Percentile values for muscular strength field tests in children aged 6 to 17 years: influence of weight status. The Journal of Strength \& Conditioning Research, 23(8), 2295-2310.

Çolak, T., Bamaç, B., Aydin, M., Meriç, B., \& Özbek, A. (2004). Physical fitness levels of blind and visually impaired goalball team players. Isokinetics and Exercise Science, 12(4), 247-252.

Davis, R.W. (2011). Teaching disability sport: A guide for physical educators, 2nd ed. Champaign: Human Kinetics.

Duthie, G. M., Pyne, D. B., Ross, A. A., Livingstone, S. G., \& Hooper, S. L. (2006). The reliability of ten-meter sprint time using different starting techniques. The Journal of Strength \& Conditioning Research, 20(2), 246 - 251. 
Đorđević, S., Mitrović, N., Zrnzević, J., Kudlaček, M., \& Jorgić, B. (2018). Relationship between body composition and postural disorder in goalball athletes: pilot study. TIMS. Acta, 12(1), 17-23.

Ellis, L., Gastin, P., Lawrence, S., Savage, B., Buckeridge, A., Stapff, A., et al. (2000). Protocols for the physiological assessment of team sport players. In C. Gore, Physiological tests for elite athletes (pp. 128144). Champaign, Illinois: Human Kinetics.

Goulart-Siqueira, G., Benítez-Flores, S., Ferreira, A., Zagatto, A., Foster, C., \& Boullosa, D. (2019). Relationships between different field test performance measures in elite goalball players. Sports, 7(1), 2-7.

Hermassi, S., Van den Tillaar, R., Khlifa, R., Chelly, M.S., \& Chamari, K. (2015). Comparison of in-season-specific resistance vs. a regular throwing training program on throwing velocity, anthropometry, and power performance in elite handball players. The Journal of Strength \& Conditioning Research, 29(8), 2105-2114.

International blind sports federation (2019). Goalball rules and regulations 2018-2020, version 1.2. Retrieved July 25, 2019 from the World Wide Web: http://www.ibsasport.org/sports/files/1008-Rules-2018-2020IBSA-Goalball-Rules-and-Regulations-(v1.2)-(Effective-1-July-2019).pdf.

Jorgić, B., Aleksandrović, M., Živković, D., Utvić, N., \& Popović, I. (2018). An analysis of the statistical parameters of goalball matches which might provide team advantage. In D. Škegro, I. Belčić, G. Sporiš \& T. Krističević (Eds.) 12 World Congress of Performance Analysis of Sport, ISPAS (pp. 63-67). Zagreb: Faculty of Kinesiology.

Karakaya, İ.Ç., Aki, E., \& Ergun, N. (2009). Physical fitness of visually impaired adolescent goalball players. Perceptual and Motor Skills, 108(1), 129-136.

Karakoc, O. (2016). Muscle strength and flexibility without and with visual impairments judoka's. International Education Studies, 9(5), 12-17.

Link, D., \& Weber, C. (2018). Finding the gap: An empirical study of the most effective shots in elite goalball. PloS one, 13(4), 1-11.

Molik, B., Morgulec-Adamowicz, N., Kosmol, A., Perkowski, K., Bednarczuk, G., Skowroński, W., et al. (2015). Game performance evaluation in male goalball players. Journal of Human Kinetics, 48(1), 43-51.

Monezi, L.A., Magalhães, T.P., Morato, M. P., Mercadante, L. A., Furtado, O.L.P.D.C., \& Misuta, M.S. (2019). Time-motion analysis of goalball players in attacks: Differences of the player positions and the throwing techniques. Sports Biomechanics, 18(5), 470-481

Morato, M.P., Gomes, M.S.P., \& Almeida, J.J.G. (2012). Os processos auto-organizacionais do goalball (The selforganizations processes of goalball). Revista Brasileira de Cięncias do Esporte, 34(3), 741-760. In Portuguese

Morato, M. P., Menezes, R. P., Fonseca, S., \& Furtado, O.L.P.D.C. (2018). Faster balls increase the probability of scoring a goal in female and male elite goalball. Revista Brasileira de Ciências do Esporte, 40(4), 427-434.

dos Santos Alves, I., Kalva-Filho, C.A., Aquino, R., Travitzki, L., Tosim, A., Papoti, M., et al. (2018). Relationships between aerobic and anaerobic parameters with game technical performance in elite goalball athletes. Frontiers in Physiology, 9(1636), 1-10.

Paravlić, A., Aleksandrović, M., Živković, D., Radovanović, D., Madić, D., Đorđević, S., et al. (2015). The effects of exercise programs on visually impaired children: A systematic review study. Facta Universitatis series Physical Education and Sport, 13(2), 193-201.

Scherer, R.L., Karasiak, F. C., da Silva, S.G., \& Petroski, É.L. (2012). Morphological profile of goalball athletes. European Journal of Human Movement, 28, 1-13.

Utvić, N., Arsenijević, R., \& Lilić, L. (2018). Connection of anthropometric characteristics and motor abilities in the selected shoot speed at goalball: Pilot study. Zbornik radova Uciteljskog fakulteta PrizrenLeposavić, 12, 189-199.

Van den Tillaar, R., \& Marques, M.C. (2013). Reliability of seated and standing throwing velocity using differently weighted medicine balls. Journal of Strength \& Conditioning Research, 27(5), 1234-123.

Van Rheenen, D. (2016). The blind leading the blind: Goalball as engaged scholarship. Journal of Postsecondary Education and Disability, 29(1), 25-34.

Yeadon, M.R., Kato, T., \& Kerwin, D.G. (1999). Measuring running speed using photocells. Journal of Sports Sciences, 17(3), 249-257. 


\section{UTICAJ NEKIH MOTORIČIH SPOSOBNOSTI NA BRZINU BACANJA LOPTE U GOLBALU: PILOT ISTRAŽIVANJE}

Cilj istraživanja je bio da se utvrdi uticaj brzine i eksplozivne snage na brzinu bacanja lopte u Golbalu. Uzorak ispitanika je činilo 12 golbalista prosečne starosti (25.17士8.03) godina nacionalnog i međunarodnog ranga. Za procenu brzine korišćeni su testovi trčanja na 5 i 10 metara. Za procenu eksplozivne snage korišćeni su testovi skok u dalj iz mesta i bacanje medicinke iz sedećeg položaja. Rezultati regresione analize pokazali su da ceo sitem primenjenih varijabli ima statistički značajnu povezanost $i$ uticaj na brzinu bacanja lopte. Pojedinačno posmatrano statistički značajan uticaj ima varijabla bacanje medicinke iz sedećeg položaja. Može se zaključiti da je u okviru kondicione pripreme golbalista potrebno raditi na razvoju brzine i eksplozivne snage zbog sposobnosti brzog prelaska igrača iz faze odbrane u fazu napada. Posebno je bitno razvijati eksplozivnu snagu mišića ruku i ramenog pojasa kako bi se povećala brzina bacanja lopte i stvorila mogućnost za veću efikasnost Golbal igrača.

Ključne reči: eksplozivna snaga, brzina, trening 